\title{
Enhanced activation of cerebellar regions during pitch discrimination in humans: a PET study
}

\author{
Augusto Petacchi ${ }^{*}$, Christian Kaernbach ${ }^{2}$, Rama Ratnam ${ }^{3}$, Donald A Robin ${ }^{1}$, James M Bower ${ }^{1}$ \\ From Nineteenth Annual Computational Neuroscience Meeting: CNS*2010 \\ San Antonio, TX, USA. 24-30 July 2010
}

Recent years have seen a growing debate concerning the function of the cerebellum. We have proposed that the cerebellum may be more involved in sensory than motor function, and have specifically predicted that its activity should be particularly enhanced during sensory discrimination tasks. Consistent with this hypothesis we have previously shown using functional Magnetic Resonance Imaging (fMRI) that 'finger' regions of the human cerebellum are more active during tactile discrimination tasks than during finger movement alone [1]. In this report we extend our investigation to the auditory system using PET. Auditory studies remove the confound of movement inherent in studies of other sensory systems, including the somatosensory system. Two previous PET studies have shown patterns of cerebellar activations associated to the discrimination of sound intensity and duration $[2,3]$. Here we test our hypothesis using a pitch discrimination task.

\section{Methods}

10 healthy subjects were trained to discriminate deviant tones presented with a slightly higher pitch than a standard tone, using a Go/No Go paradigm. To ensure that discrimination was performed at equivalent levels of performance for each subject, individual psychometric curves were assessed beforehand using a two-step psychoacoustic procedure. The auditory stimuli were harmonic complexes with a fundamental frequency $\left(f_{0}\right)$ and 20 harmonics $(3 \mathrm{~dB} /$ octave roll-off in the spectrum level), $300 \mathrm{~ms}$ duration (rise/fall time $=80 \mathrm{~ms}$ ), presented through earphones at a level of $75 \mathrm{~dB}$ SPL and with a $1 \mathrm{sec}$ inter-onset interval. Each subject underwent an anatomical MRI scan for coregistration purposes, and 12 independent PET scans, 2 during each of 6

\footnotetext{
* Correspondence: petacchi@uthscsa.edu

${ }^{1}$ Research Imaging Institute, University of Texas Health Science Center at San Antonio, San Antonio, TX 78229, USA
}

conditions: Rest (silent rest, eyes closed); Passive Listening (attending to the standard tones); Pitch Discrimination at 4 different performance levels (mentally detecting deviant tones slightly higher in pitch among these standard tones). To control for motor-related confounds subjects were required to respond covertly. However, they were required to indicate subjective pitch discriminability at the end of each scan involving a Pitch Discrimination condition. Moreover, before and after a scan involving a PD condition, subjects performed a test-retest Pitch Discrimination run of the same performance level as that in the corresponding scan, during which mouse button responses were acquired.

\section{Results}

Conditional contrast analysis of regional cerebral blood flow (rCBF) data outlined activation during the Passive Listening condition in both the auditory cortices and the cerebellum (deep floccular/parafloccular regions, $z=-48,[4])$, however, the Pitch Discrimination conditions were associated with significant increases in both cerebellar activation volumes and magnitudes. Performance correlation analysis did not reveal regions in which $\mathrm{rCBF}$ showed a significant linear covariation with the performance level during the Pitch Discrimination conditions.

These results are consistent our previous neuroimaging findings in the somatosensory domain [1], and extend to an additional sensory system evidence that the cerebellum is, in fact, more active during discriminative than passive sensory conditions. Furthermore, these results complement our recent psychophysical data showing a significant pitch discrimination deficit in cerebellar patients [5]. From an anatomical point of view, these results provide physiological validation of studies 
reporting direct auditory projections from the cochlea to the floccular/parafloccular regions of the cerebellum $[6,7]$.

\section{Author details}

${ }^{1}$ Research Imaging Institute, University of Texas Health Science Center at San Antonio, San Antonio, TX 78229, USA. ²Dept. of Psychology, Christian-

Albrechts-Universität zu Kiel, Kiel, 24118, Germany. ${ }^{3}$ Biology Dept., University of Texas at San Antonio, San Antonio, , San Antonio, TX 78249, USA.

Published: 20 July 2010

\section{References}

1. Gao JH, Parsons LM, Bower JM, Xiong J, Li J, Fox PT: Cerebellum implicated in sensory acquisition and discrimination rather than motor control. Science 1996, 272:545-547.

2. Belin P, McAdam S, Smith B, Savel S, Thivard L, Samson S, Samson Y: The functional anatomy of sound intensity discrimination. J Neurosci 1998, 18:6388-6394.

3. Belin P, McAdams S, Thivard L, Smith B, Savel S, Zilbovicius M, Samson S, Samson $Y$ : The neuroanatomical substrate of sound duration discrimination. Neuropsychologia 2002, 40:1956-1964.

4. Schmahmann JD, Doyon J, Toga AW, Petrides M, Evans AC: MRI atlas of the human cerebellum. San Diego: Academic Press. 2000, 167.

5. Parsons LM, Petacchi A, Schmahmann JD, Bower JM: Pitch perception in cerebellar patients: Evidence for a sensory deficit. Brain Res 2009, 1303:84-96.

6. Brozoski TJ, Ciobanu L, Bauer CA: Central neural activity in rats with tinnitus evaluated with manganese-enhanced magnetic resonance imaging (MEMRI). Hear. Res. 2007, 228:168-179.

doi:10.1186/1471-2202-11-S1-P84

Cite this article as: Petacchi et al.: Enhanced activation of cerebellar regions during pitch discrimination in humans: a PET study. $B M C$ Neuroscience 2010 11(Suppl 1):P84.

\section{Submit your next manuscript to BioMed Central and take full advantage of:}

- Convenient online submission

- Thorough peer review

- No space constraints or color figure charges

- Immediate publication on acceptance

- Inclusion in PubMed, CAS, Scopus and Google Scholar

- Research which is freely available for redistribution

Submit your manuscript at www.biomedcentral.com/submit
C Biomed Central 